\title{
Phenotypic and Symbiotic Diversity of Rhizobia Isolated from Root Nodules of Soybean [Glycine max (L.) Merrill] in Côte d'Ivoire
}

\author{
Amani Kouadio ${ }^{1}$, Konate Ibrahim ${ }^{1 *}$, Mako François De Paul N'gbesso ${ }^{2}$, Attien Yao \\ Paul $^{1}$, Lassina Fondio ${ }^{2}$, Abdelkarim Filali-Maltouf ${ }^{3}$ and Tidou Abiba Sanogo ${ }^{1}$ \\ ${ }^{1}$ UFR Agro-forestry and Environment, Department of Biochemistry and Microbiology, \\ Laboratory of Agrovalorization, Jean Lorougnon Guede University, \\ B.P: 150 Daloa, Côte d'Tvoire \\ ${ }^{2}$ National Center for Agronomic Research (CNRA), 01 BP 633 Bouaké 01, Côte d'Ivoire \\ ${ }^{3}$ Faculty of Sciences, Laboratory of Microbiology and Molecular Biology, University \\ Mohammed V-Agdal, Rabat, Morocco \\ *Corresponding author
}

\begin{abstract}
A B S T R A C T
Soybean [Glycine max (L.) Merrill] is a legume known for nitrogen fixation interacting with efficient Bradyrhizobium strains. In Côte d'Ivoire, the Bradyrhizobium inoculums used in soybean production is a foreign strain, which requires the search for indigenous strains adapted to Ivorian soils. The present study aimed to isolate and select rhizobial bacteria from soybeans grown on soils sampled from six localities in the central-western region of Côte d'Ivoire. Thirty bacteria were obtained from the nodules of plants grown on soils of two localities that had previously received soybean cultivation (Gonate North and South). These isolates were coded as RSC and identified as being able to genus Bradyrhizobium (slow growth) and Sinorhizobium (intermediate growth) depending on cultural and morphological characteristics. Except for RSC 327 and RSC 330, all isolates were authenticated and were able to nodulate the host plant in controlled culture. The isolates RSC 309, RSC 310, RSC 312, RSC 323, RSC 324, RSC 325 and RSC 326 were efficient and significantly ( $\mathrm{P}<5 \%$ ) increased the number and weight of the nodules, the height and plant biomass. Moreover, these same isolates also showed a high tolerance to salt $(\mathrm{NaCl})$ added in YEM media at a concentration ranging from 4 to $5 \%$. Based on the symbiotic and physiological characteristics, isolates RSC 309, RSC 310, RSC 312, RSC 323, RSC 324 and RSC 325 could be recommended as the native soybean inoculums under soil and climatic conditions of Côte d'Ivoire.
\end{abstract}

Keywords

Rhizobia, Soybean,

Native strains,

Selection,

Côte d'Ivoire

Article Info

Accepted:

07 February 2019

Available Online:

10 March 2019

\section{Introduction}

Nitrogen is an essential nutrient for plant growth and development. Much of this nitrogen is provided to cropping systems in the form of industrially produced nitrogen fertilizers. However, using of fertilizers has become detrimental for soil fertility and led to 
worldwide ecological problems as well as affects the human health (Vitousek, 1997; Yusuf et al., 2009). Thus, maintaining and increasing soil fertility through Biological Nitrogen Fixation (BNF) are the major agricultural priorities in many parts of countries development. BNF is the cheapest and ecologic way in which micro-organisms interacting with leguminous plants such as soybean [Glycine max (L.) Merrill] fix aerobic nitrogen (Franche et al., 2009).

Soybean is a legume cultivated for seeds which are highly rich in protein $(40 \%)$ and oil (20 \%) (Nyabyenda, 2005; Cahuzac-Picaud, 2010). Many leguminous crops provide some protein, but soybean is the only available crop that provides an inexpensive and high quality source of protein comparable to meat, poultry and eggs. It also provides useful crop residues for animal feed or left in the field to decompose, thereby increasing the organic matter content of the soil (Mahamood et al., 2009). On a global scale, the average yearly amount of nitrogen fixed by Bradyrhizobium japonicum is about $450 \mathrm{~kg}$ nitrogen $\mathrm{ha}^{-1}$ in a soybean crop, representing about $90 \%$ of the nitrogen requirement (Giller, 2001; Zablotowicz and Reddy, 2004). Maintaining this significant nitrogen input can be important for economically sustainable soybean yields, especially in soils containing low available soil nitrogen (Klubeck et al., 1988; Zablotowicz and Reddy, 2004). This capacity of soybean to fix nitrogen reduces the need to supply crops with synthetic nitrogen fertilizers.

In Côte d'Ivoire, attempts have been made to conduct research on soybean growth and production. However, the studies have focused solely on evaluating the effective compatibility of soybean varieties with the Bradyrhizobium japonicum (IRAT FA3) provided by France for two decades for inoculums production (N'Gbesso et al., 2010).
Recent results from these studies have shown differences in efficacy between $B$. japonicum strain IRAT FA3 and introduced soybean genotypes in the country (N'Zi et al., 2015; N'Gbesso et al., 2017). In addition, there is little information available on native symbionts of soybeans. Thus, to obtain highly effective symbiotic soybean bacteria, it is necessary to search for native Bradyrhizobium in the laboratory and in greenhouse conditions. Hence, the objective of our investigation is to isolate and evaluate the symbiotic efficacy of soybean Bradyrhizobium sp from Côte d'Ivoire.

\section{Materials and Methods}

The study was conducted on greenhouse in Jean Lorougnon Guédé University (Daloa, Côte d'Ivoire) experimental site $\left(6^{\circ} 54^{\prime} 27.37^{\prime \prime} \mathrm{N} ; 6^{\circ} 26^{\prime} 11.26^{\prime \prime} \mathrm{W}\right)$ in 2017 2018. The soybean [Glycine max (L.) Merrill] cultivar Piramama was used for the isolates trapping and authentication tests.

\section{Soil sampling and Rhizobia trapping}

Soil samples were collected from six localities in Daloa area in the fields which soybean and over leguminous were previously growing in the three latest year (Table 1). Sampling was done following the procedure outlined by Barker and Pilbean (2007). Soil samples were randomly collected from several places at 0-20 $\mathrm{cm}$ depth from each plot and they were placed in pots $(4 \mathrm{Kg} /$ pot $)$ previously disinfected by sodium hypochlorite. Pots were arranged in a completed randomly block design in greenhouse with five repetitions.

\section{Isolation and morphological characterization of soybean Rhizobia}

The Rhizobia were isolated from sterile nodules and purified with the protocol using Yeast Extract Mannitol (YEM) agar supplied 
with $0.02 \%$ Congo red (Vincent, 1970). At the harvest, soybean root nodules were washed first by water and then immersed in $0.1 \%$ acidified $\mathrm{HgCl}_{2}$ for 5 minutes. The nodules were transferred in a beaker containing $10 \mathrm{ml}$ of $95 \%$ ethanol for $2-3$ minutes. The nodules were rinsed in 6 changes of sterile water and each nodule was transferred in hemolysis tube containing $1 \mathrm{ml}$ sterilized distilled water. Each nodule was crushed with sterile glass rod. The aliquot of the suspension was transferred on YEM agar plate. The plates were incubated at $28{ }^{\circ} \mathrm{C}$ for 4-7 days. Some characteristics colony, morphology and gram staining properties were observed.

\section{Confirmation of isolated Rhizobia through nodulation test}

The nodulation capacity of the bacteria isolated from soybean was confirmed by inoculation tests on sterile sand. Each isolate was grown on YEM liquid medium to exponential phase. Seeds of soybean cultivar Piramama were surface-sterilized as before and sown on plastic pots containing sterile sand. Seven days after sowing, each plant of a pot except the controls was inoculated by $1 \mathrm{ml}$ of broth culture of each isolate. Control pots were included for an unfertilized and an uninoculated negative control (TO) and uninoculated but nitrogen fertilized $(0.05 \%$ $\mathrm{KNO}_{3}$ ) positive control (TN). Plants were supplied with distilled water every two days, and they were saturated once a week with a nitrogen-free nutrient solution. Furthermore, $\mathrm{TN}$ control received weekly $0.05 \%$ (w/v) $\mathrm{KNO}_{3}$ as nitrogen source.

Plants were harvested 45 day after sowing (DAS), evaluating nodule number, nodule weight, plant height and biomass weight. The experiment was statistically laid out with three replications using randomized black design (Somasegaran and Hoben, 1994).

\section{Physiological characteristic: Salt tolerance}

Salt tolerance was determined on YEM agar plates containing from 0 to $10 \%$ (w/v) $\mathrm{NaCl}$ concentrations. This test was carried out on YEM agar plates. Petri dishes containing defined medium were subdivided into squares and each square was inoculated with $10 \mu \mathrm{l}$ of $48 \mathrm{~h}$ bacterial YEM broth Konate et al., 2015). After 7 days of incubation at $28{ }^{\circ} \mathrm{C}$, bacterial growth was compared to the controls.

\section{Statistical analysis}

The data of measured parameters recorded were pooled together and subjected to statistical analysis using the STATISTICA program (7.1). The strains tolerance was subjected of $\mathrm{Chi}^{2}$ of Pearson test. Plant growth and nodulation parameters were subjected by analysis of variance. The difference between the treatments means were evaluated at $5 \%$ level of significance using Fisher's LSD test.

\section{Results and Discussion}

\section{Soil sampling and Rhizobia trapping}

Analysis of the variance revealed a significant difference $(\mathrm{P}<5 \%)$ between nodulation and soils samples provenance. Indeed, soybean [Glycine max (L.) Merrill] cultivar Piramama was able to induce nodule formation only on soils which were previous soybean cultural. The best nodulation was obtained on Gonate SODEFOR soil with an average of 38 nodules per plant (Table 2). However, soils with a history of cowpea, green gram, groundnuts and bean cultural have been unable to promote nodules formation. These observations indicate that soybean can form nitrogen fixing nodules only in symbiosis with a very narrow range of symbionts. These results corroborate those of Karaboneye (2013), Kumar and Reddy (2018). According to those authors, there are very few native rhizobia strains that 
are compatible with soybean lines in tropical soils. Thus, nodules formation on soybean roots by native rhizobia is closely related to the cultural history of soils, the cultivated variety and compatibility between a variety and the bacterial strain present in the soil (N'Gbesso et al., 2017).

\section{Isolation and morphological characterization of soybean Rhizobia}

Thirty (30) isolates bacteria were obtained from the root nodules of soybean grown on soils from various sites of center-west of Côte d'Ivoire (Table 3). Isolates obtained in this study were coded RSC (Rhizobia isolated from Soybean in Côte d'Ivoire) and were generally circular, mucilaginous, pink or white color on YEM agar medium. Microscopic examination revealed that all isolates were rod shaped and gram negative. Similar characteristics were observed by over authors on isolates of soybean root nodules in several parts of the world (Sharma et al., 2010; Jadhav, 2013; Kapembwa et al., 2016). These characteristics have been described by Jordan (1982) as distinctive features of Rhizobia. In addition, colonies diameter and generations times had varied from 1 to $7 \mathrm{~mm}$ and 2 to 7 days respectively. Based on these latest, isolates could belong to the genus Bradyrhizobium (slow growth) and Sinorhizobium (intermediary growth) (Sadowasky et al., 1983; Hossain et al., 2012).

Confirmation and preliminary screening of soybean Rhizobia effectiveness through nodulation test

All isolates bacteria, except RSC 327 and RSC 330 were authenticated as soybean symbiont (Table 3). Therefore, authentic isolates showed a large diversity in their capacity to infect the host plant and to improve plant growth.

Isolates influenced significantly ( $\mathrm{P}<5 \%)$ number and weight of nodules. Isolates RSC 325 and RSC 309 produced the highest number of nodules (39 and 42.33 plant $^{-1}$ respectively) (Figure 1). Isolates RSC 323 and RSC 309 induced the highest weight of nodules $423.33 \mathrm{mg}$ and $446.67 \mathrm{mg}$ respectively).

Table.1 Soils sampling origin and cultural history

\begin{tabular}{|c|c|c|}
\hline Sampling area & Geographical Coordinates & Cultural history \\
\hline Daloa & $6^{\circ} 54^{\prime} 31.76^{\prime \prime} \mathrm{N} ; 6^{\circ} 26^{\prime} 14.99^{\prime \prime} \mathrm{W}$ & greengram \\
\hline Bribouo & $6^{\circ} 52^{\prime} 22.12^{\prime \prime} \mathrm{N} ; 6^{\circ} 30^{\prime} 11.96^{\prime \prime} \mathrm{W}$ & cowpea \\
\hline Gbetitapea & $6^{\circ} 47^{\prime} 31.35^{\prime \prime} \mathrm{N} ; 6^{\circ} 27^{\prime} 7.84^{\prime \prime} \mathrm{W}$ & groundnuts \\
\hline Gonate SODEFOR & $6^{\circ} 53^{\prime} 59.14^{\prime \prime} \mathrm{N} ; 6^{\circ} 10^{\prime} 54.89^{\prime \prime} \mathrm{W}$ & Soybean \\
\hline $\begin{array}{l}\text { Gonate North } \\
\text { Tapeguhe }\end{array}$ & $\begin{array}{l}6^{\circ} 55^{\prime} 36.59^{\prime \prime} \mathrm{N} ; 6^{\circ} 15^{\prime} 31.76^{\prime \prime} \mathrm{W} \\
6^{\circ} 57^{\prime} 25.48^{\prime \prime} \mathrm{N} ; 6^{\circ} 28^{\prime} 22.69^{\prime \prime} \mathrm{W}\end{array}$ & $\begin{array}{c}\text { Soybean } \\
\text { Common bean }\end{array}$ \\
\hline
\end{tabular}

Table.2 Nodules means number according to soils origin

\begin{tabular}{|l|c|c|c|c|c|c|}
\hline Soil sampling sites & Bribouo & Daloa & Gbetitapea & Gonate N & Gonate S & Tapeguhe \\
\hline Nodules number & 0 & 0 & 0 & $07 \pm 2$ & $38 \pm 4$ & 0 \\
\hline
\end{tabular}

$\mathrm{N}=$ North $\mathrm{S}=$ South 
Table.3 Effect of native soybean root nodule isolates on nodule number, nodule weight, plant height and biomass of soybean on sand pot

\begin{tabular}{|c|c|c|c|c|c|}
\hline Treatment & $\begin{array}{l}\text { Nodule } \\
\text { number }\end{array}$ & $\begin{array}{l}\text { nodule weight } \\
\left(\text { mg plant }^{-1}\right)\end{array}$ & $\begin{array}{c}\text { plant height } \\
(\mathrm{cm})\end{array}$ & $\begin{array}{l}\text { Fresh biomass } \\
\quad\left(\text { g plant }^{-1}\right)\end{array}$ & $\begin{array}{l}\text { Dry biomass } \\
\left(\text { g plant }^{-1}\right)\end{array}$ \\
\hline RSC 301 & $10.67 f$ & $83.33 \mathrm{fg}$ & $31.33 \mathrm{ab}$ & $5.52 \mathrm{cde}$ & $1.07 \mathrm{de}$ \\
\hline RSC 302 & $3.33 \mathrm{~g}$ & $53.33 \mathrm{~g}$ & $16.33 \mathrm{~d}$ & $5.15 \mathrm{de}$ & $1.05 \mathrm{e}$ \\
\hline RSC 303 & $4 g$ & $61 \mathrm{~g}$ & $17.8 \mathrm{~d}$ & $5.43 \mathrm{de}$ & $1.36 \mathrm{cde}$ \\
\hline RSC 304 & $5.33 \mathrm{~g}$ & $68.33 \mathrm{~g}$ & $26.67 \mathrm{c}$ & $6.13 \mathrm{de}$ & $1.22 \mathrm{de}$ \\
\hline RSC 305 & $3.33 \mathrm{~g}$ & $46.67 \mathrm{~g}$ & $26 c$ & $4.50 \mathrm{de}$ & $0.86 \mathrm{e}$ \\
\hline RSC 307 & $3.67 \mathrm{~g}$ & $51.66 \mathrm{~g}$ & $30 \mathrm{bc}$ & $6.70 b c$ & $1.22 \mathrm{de}$ \\
\hline RSC 308 & $4 \mathrm{~g}$ & $40 \mathrm{~g}$ & $27.67 \mathrm{c}$ & $7.06 \mathrm{bc}$ & $1.25 \mathrm{de}$ \\
\hline RSC 309 & $42.33 a$ & $446.67 \mathrm{a}$ & $37.23 \mathrm{a}$ & 7.82ab & $2.11 \mathrm{a}$ \\
\hline RSC 310 & $38 b$ & $403.33 b$ & $32.26 \mathrm{ab}$ & $7.07 b c$ & $1.88 \mathrm{~b}$ \\
\hline RSC 312 & $27 d$ & $380 \mathrm{c}$ & $27.80 \mathrm{c}$ & $6.32 \mathrm{~cd}$ & $1.48 \mathrm{~cd}$ \\
\hline RSC 313 & $10 f$ & $86.67 \mathrm{fg}$ & $28 \mathrm{bc}$ & $5.12 \mathrm{de}$ & $1.05 \mathrm{e}$ \\
\hline RSC 314 & $7.33 f g$ & $81.67 \mathrm{fg}$ & $29 \mathrm{bc}$ & $6.52 \mathrm{c}$ & $1.33 \mathrm{cde}$ \\
\hline RSC 315 & $6.67 \mathrm{fg}$ & $66.67 \mathrm{~g}$ & $29.67 \mathrm{bc}$ & $6.77 b c$ & $1.33 \mathrm{cde}$ \\
\hline RSC 316 & $3.33 \mathrm{~g}$ & $53.33 \mathrm{~g}$ & $27 \mathrm{c}$ & $5.47 \mathrm{de}$ & $1.21 \mathrm{de}$ \\
\hline RSC 317 & $3.67 \mathrm{~g}$ & $58.33 \mathrm{~g}$ & $27.5 \mathrm{c}$ & $5.77 \mathrm{~cd}$ & $1.35 \mathrm{cde}$ \\
\hline RSC 318 & $20.33 \mathrm{e}$ & $261.67 d$ & $32.33 \mathrm{ab}$ & $8.2 \mathrm{a}$ & $2.97 \mathrm{a}$ \\
\hline RSC 319 & $7.33 \mathrm{fg}$ & $96.67 \mathrm{fg}$ & $24.33 c$ & $5.55 \mathrm{~cd}$ & $1.22 \mathrm{de}$ \\
\hline RSC 320 & $6 \mathrm{~g}$ & $70 \mathrm{~g}$ & $26.67 \mathrm{c}$ & $4.9 \mathrm{de}$ & $0.92 \mathrm{e}$ \\
\hline RSC 321 & $4.33 \mathrm{~g}$ & $51.66 \mathrm{~g}$ & $28.73 b c$ & $5.24 \mathrm{de}$ & $1.09 \mathrm{de}$ \\
\hline RSC 322 & $7.66 f g$ & $93.33 \mathrm{fg}$ & $31 \mathrm{ab}$ & $6.06 \mathrm{~cd}$ & $1.24 \mathrm{de}$ \\
\hline RSC 323 & $38 b$ & $423.33 \mathrm{ab}$ & $34.57 \mathrm{ab}$ & 7.51ab & $1.96 \mathrm{~b}$ \\
\hline RSC 324 & $31.67 \mathrm{c}$ & $390 \mathrm{bc}$ & $30.67 \mathrm{ab}$ & 7.50ab & $2.01 \mathrm{~b}$ \\
\hline RSC 325 & $39.00 \mathrm{~b}$ & $408.33 b$ & 33.67ab & 7. 79ab & $1.94 \mathrm{~b}$ \\
\hline RSC 326 & $11 \mathrm{f}$ & $140 \mathrm{e}$ & $31.1 \mathrm{ab}$ & $6.13 \mathrm{~cd}$ & $1.77 \mathrm{bc}$ \\
\hline RSC 327 & - & - & $27.90 \mathrm{c}$ & $6.03 \mathrm{~cd}$ & $1.35 \mathrm{cde}$ \\
\hline RSC 328 & $7.33 \mathrm{fg}$ & $83.33 \mathrm{fg}$ & $27.80 \mathrm{c}$ & $5.58 \mathrm{~cd}$ & $1.26 \mathrm{de}$ \\
\hline RSC 329 & $5.67 \mathrm{~g}$ & $76.67 \mathrm{~g}$ & $28.67 \mathrm{bc}$ & $6.62 c$ & $1.33 \mathrm{cde}$ \\
\hline RSC 330 & - & - & $27.90 \mathrm{c}$ & $5.92 \mathrm{~cd}$ & $1.19 \mathrm{de}$ \\
\hline RSC 331 & $10.66 f$ & $113.33 \mathrm{ef}$ & $29 \mathrm{bc}$ & $5.72 \mathrm{~cd}$ & $1.07 \mathrm{de}$ \\
\hline TN & - & - & $30.50 \mathrm{bc}$ & $7.07 \mathrm{bc}$ & $1.73 b c$ \\
\hline TNN & - & - & $25.33 c$ & $4.62 \mathrm{e}$ & $0.86 \mathrm{e}$ \\
\hline $\begin{array}{c}\text { LSD (5 } \\
\%)\end{array}$ & 4.33 & 34.33 & 6.58 & 0.8 & 0.42 \\
\hline
\end{tabular}

In the column, means followed by the same letter did not differ significantly at $5 \%$ level by the LSD test. TN: uninoculated and fertilized control; T0: uninoculated and unfertilized control. 
Int.J.Curr.Microbiol.App.Sci (2019) 8(3): 766-774

Table.4 Tolerance of soybean Rhizobia to different concentrations of $\mathrm{NaCl}$

\begin{tabular}{|c|c|c|c|c|c|c|c|c|c|c|}
\hline \multirow[b]{2}{*}{ Isolates } & \multicolumn{10}{|c|}{ Salt tolerance } \\
\hline & $0 \%$ & $0.5 \%$ & $1 \%$ & $1.5 \%$ & $2 \%$ & $3 \%$ & $4 \%$ & $5 \%$ & $8 \%$ & $10 \%$ \\
\hline RSC 301 & $3+$ & $2+$ & $2+$ & $1+$ & - & - & - & - & - & - \\
\hline RSC 302 & $3+$ & $2+$ & $2+$ & $2+$ & $1+$ & $1+$ & - & - & - & - \\
\hline RSC 303 & $3+$ & $2+$ & $2+$ & $2+$ & $1+$ & - & - & - & - & - \\
\hline RSC 304 & $3+$ & $2+$ & $2+$ & $2+$ & $1+$ & - & - & - & - & - \\
\hline RSC 305 & $3+$ & $2+$ & $2+$ & $2+$ & $1+$ & - & - & - & - & - \\
\hline RSC 307 & $3+$ & $2+$ & $2+$ & $2+$ & $1+$ & - & - & - & - & - \\
\hline RSC 308 & $3+$ & $2+$ & $2+$ & $2+$ & $1+$ & - & - & - & - & - \\
\hline RSC 309 & $3+$ & $2+$ & $2+$ & $2+$ & $1+$ & $1+$ & $1+$ & - & - & - \\
\hline RSC 310 & $3+$ & $2+$ & $2+$ & $2+$ & $1+$ & $1+$ & $1+$ & $1+$ & $1+$ & $1+$ \\
\hline RSC 312 & $3+$ & $2+$ & $2+$ & $2+$ & $1+$ & $1+$ & $1+$ & $1+$ & - & - \\
\hline RSC 313 & $3+$ & $2+$ & $2+$ & $2+$ & $1+$ & - & - & - & - & - \\
\hline RSC 314 & $3+$ & $2+$ & $2+$ & $2+$ & $1+$ & - & - & - & - & - \\
\hline RSC 315 & $3+$ & $2+$ & $2+$ & $2+$ & $1+$ & - & - & - & - & - \\
\hline RSC 316 & $3+$ & $2+$ & $2+$ & $2+$ & $1+$ & - & - & - & - & - \\
\hline RSC 317 & $3+$ & $2+$ & $2+$ & $2+$ & $1+$ & - & - & - & - & - \\
\hline RSC 318 & $3+$ & $2+$ & $2+$ & $2+$ & $1+$ & $1+$ & - & - & - & - \\
\hline RSC 319 & $3+$ & $2+$ & $2+$ & $2+$ & $1+$ & - & - & - & - & - \\
\hline RSC 320 & $3+$ & $2+$ & $2+$ & $2+$ & $1+$ & - & - & - & - & - \\
\hline RSC 321 & $3+$ & $2+$ & $2+$ & $2+$ & $1+$ & - & - & - & - & - \\
\hline RSC 322 & $3+$ & $2+$ & $2+$ & $2+$ & $1+$ & - & - & - & - & - \\
\hline RSC 323 & $3+$ & $2+$ & $2+$ & $2+$ & $1+$ & $1+$ & $1+$ & $1+$ & - & - \\
\hline RSC 324 & $3+$ & $2+$ & $2+$ & $2+$ & $1+$ & $1+$ & $1+$ & - & - & - \\
\hline RSC 325 & $3+$ & $2+$ & $2+$ & $2+$ & $1+$ & $1+$ & $1+$ & - & - & - \\
\hline RSC 326 & $3+$ & $2+$ & $2+$ & $2+$ & $1+$ & $1+$ & - & - & - & - \\
\hline RSC 327 & $3+$ & $2+$ & $2+$ & $2+$ & $1+$ & - & - & - & - & - \\
\hline RSC 328 & $3+$ & $2+$ & $2+$ & $2+$ & $1+$ & - & - & - & - & - \\
\hline RSC 329 & $3+$ & $2+$ & $2+$ & $2+$ & $1+$ & - & - & - & - & - \\
\hline RSC 330 & $3+$ & $2+$ & $2+$ & $2+$ & $1+$ & - & - & - & - & - \\
\hline RSC 331 & $3+$ & $2+$ & $2+$ & $2+$ & $1+$ & - & - & - & - & - \\
\hline
\end{tabular}

3+: Very good growth; 2+: Good growth; 1+: moderate growth; -: no growth

Fig.1 Soybean cultivar Piramama plants inoculated by the isolates RSC 309 (A) and RSC 325

(B) and the uninoculated plants (C)

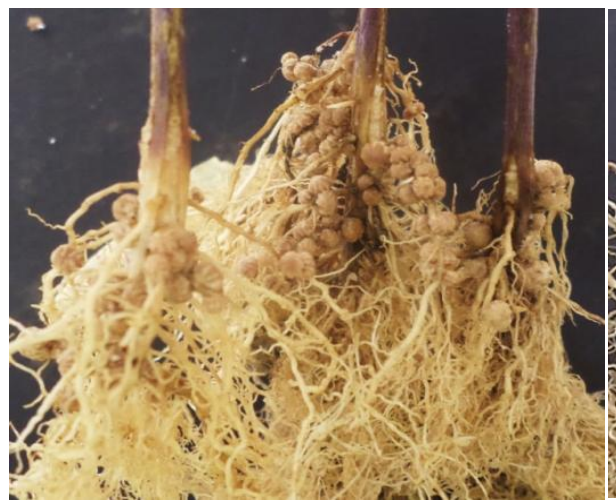

A

Considering the growth of plants, the results revealed that all isolates produced

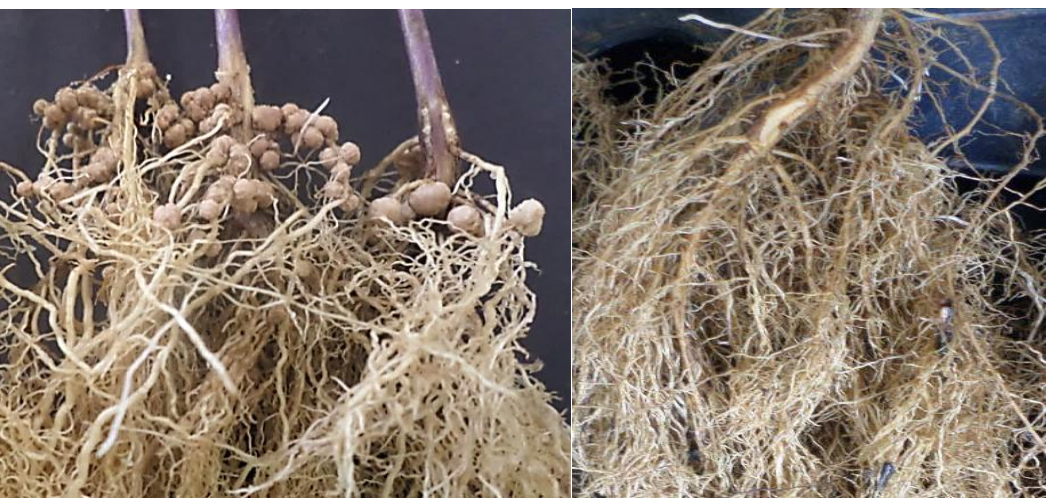

B

C significantly higher biomass and plant height compared to negative control (T0). The higher 
biomasses were recorded by the isolates RSC 318 (2.97 g) and RSC 309 (2.11 g). The isolates RSC 310, RSC 323, RSC 324 and RSC 326 were found statistically similar and stimulated plant growth than synthetic nitrogen $\left(\mathrm{KNO}_{3}\right)$ applied on positive control (TN). The lowest was found in negative control and isolates RSC 305 and RSC 320. These observations are in agreement with previous reports by N'Gbesso et al., (2017) on inoculation of over soybean cultivars with native selected Bradyrhizobium strains, which showed increased survival percentage in seedlings and greater biomass production in all inoculated plant. Some researchers attributed the higher nodulation and biomass yields of inoculated plants to high nitrogen fixation incorporated into nitrogen biosynthesis (Sharma et al., 2000; Hossain et al., 2012).

\section{Physiological characteristic: salt tolerance}

Isolates exhibited a wide tolerance to salt stress (Table 4). All isolates grew on the YEM agar medium containing up $2 \%$ of $\mathrm{NaCl}$ excepted isolate BSC 301. Beyond this concentration, the percentage of tolerant strains decreased rapidly. Only $26 \%$ of strains supported $3 \%$ of salt concentrations. Of these, isolates RSC 309, RSC 324 and RSC 325 tolerated $4 \% \mathrm{NaCl}$ while RSC 312 and RSC 323 showed tolerant to $5 \% \mathrm{NaCl}$. Isolate RSC 310 exhibited the highest tolerance of salt $(10 \%)$. Thus, the salt inhibitory concentrations varied among strains.

This finding corroborated previous reports which stipulated that Rhizobia could grow up to $3 \%$ of salt concentrations (Chen et al., 2000; Raza et al., 2001; El Hilali, 2006). However, over work showed that Rhizobia tolerate low salt concentrations (Zerhari et al., 2000; Maâtallah et al., 2002).
In conclusion, this study clearly reveals that the soils of Côte d'Ivoire are very poor in rhizobia, which nodules of the soybean [Glycine max (L.) Merrill], a legume introduced in 1970. However, the soils that have previously received the cultivation of this legume could generate compatible rhizobia. In fact, thirty rhizobia were isolated from the nodules of the soybean Piramama cultivar in the soils of two localities in Côte d'Ivoire (center-west). More than $93 \%$ of the isolates were authenticated, capable of nodulating the host plant and very close to Bradyrhizobium and Sinorhizobium. Symbiotic and physiological data showed that isolates RSC309, SRC310, RSC312, RSC323, RSC324 and RSC325 were particularly infectious, efficient and salt-tolerant at $4-5 \%$ of $\mathrm{NaCl}$. These six isolates have promising symbiotic and agronomic traits and could be recommended as native inoculants for the biological inoculation of soybeans under soil and climatic conditions in Côte d'Ivoire.

\section{References}

Cahuzac-Picaud M., 2010. Les huiles végétales, intérêt diététique et gastronomique. Phytothérapie, 8:113117.

Chen W. M, Lee T. M., Lam CC and Cheng CP. 2000. Characterization of halotolerant Rhizobia isolated from root nodules of Canavalia rosea from seaside areas. FEMS Microb Eco. 34, 916.

El Hilali I., 2006. La symbiose RhizobiumLupin: Biodiversité des microsymbiotes et mise en évidence d'une multiinfection nodulaire chez Lupinus luteus. Thèse de Doctorat d'Etat Es Sciences. Université Mohammed V. Rabat.

Franche C., Lindstrom K and Elmerich C., 2009. Nitrogen fixing bacteria associated with leguminous and nonleguminous plants. Plan Soil. 321: 35- 
59.

Giller K.E., 2001. Nitrogen fixation in tropical cropping systems. Second ed. CABI Publishing. Wallingford, UK, $448 \mathrm{p}$.

Hossain A. K. M. M., Mian M. H., Hakim M. A., Islam M. M. and Ferdous J., 2012. Isolation and selection of Bradyrhizobium from the root nodules of indigo plants (Indigofera tinctoria L.). Afr. J. Biotechnol. 11(58): 1218312191.

Ibrahim Konate, Adama Ouattara, Bakary Coulibaly, Raissa N.K. Guei, Kouadio Amani, Kpandji I. Kouadio, Abdelkarim Filali-Maltouf and Mathurin KOFFI. (2015). Phenotypic Diversity of Associative Bacteria Isolated from Roots and Stems of Cacao (Theobroma cacao) Tree in Daloa, Côte d'Ivoire. Int. J. Curr. Microbiol. App. Sci. 4(9): 560-570.

Jadhav R N., 2013. Isolation of rhizobia from soybean cultivated in latur area and study of its phosphate solubilization activity. Biosci. Disc., 4(1):100-103.

Jordan D.C., 1982. Transfer of Rhizobium japonicum Buchanan 1980 to Bradyrhizobium gen. nov. a genus of slow-growing root nodule bacteria from leguminous plants. Int. J. Syst. Bacteriol. 32: 136-139.

Kapembwa R., Mweetwa A M., Ngulube M. and Yengwe J. 2016. Morphological and Biochemical Characterization of Soybean Nodulating Rhizobia Indigenous to Zambia. Sustainable Agriculture Research. 5(3): 84-92.

Karaboneye F. 2013. Caractérisation de l'efficacité symbiotique des lignées africaines de soja à haute promiscuité. Mémoire de Maîtrise en Biologie. Université de Laval, Québec, Canada $123 \mathrm{p}$.

Klubeck B.P., Hendrickson L.L., Zablotowicz R.M., Skwara J.E., Varsa E.C., Smith
S., Isleib T.G., Maya J., Valdes M., Dazzo F.B., Todd R.L. and Walgenback D.D., 1988. Competitiveness of selected Bradyrhizobium japonicum strains in midwestern USA soils. Soil Science Society of America Journal, 52: 662666.

Maâtallah J., Berraho E.B., Munoz S., Sanjuan J and Lluch C., 2002. Phenotypic characterization of rhizobia isolated from chickpea (Cicer arietinum L.) growing in Moroccan soils. Agronomie. 22, 321-329.

Mahamood J. Abayomi, Y.A. and Aduloju, M.O. 2009. Comparative growth and grain yield responses of soybean genotypes to phosphorous fertilizer application. African Journal of Biotechnology 8 (6): 1030-1036.

N'Gbesso M.F.D.P., Fondio L., Coulibaly N.D and Kouame N.C., 2017. Efficacité symbiotique de cinq souches locales de rhizobiums sur les paramètres de croissance du soja. Inter. J. of Biol. and Chemic. Scie, 11(5): 2327-2340.

N'Gbesso M.F.D.P., N'guetta ASP, Kouamé $\mathrm{NC}$ and Foua B.K., 2010. Evaluation de l'efficience de l'inoculation des semences chez 11 génotypes de soja (Glycine $\max$ L. Merrill) en zone de savane de Côte d'Ivoire. Sci. Nat. 7(1):59-67.

N'Zi J-C., Koua A P., Kouassi K. D., Kahia J., Kouassi J-L., N'Guetta A. S-P and Kouamé C., 2015. Effect of inoculating seeds with Bradyrhizobium japonicum on the agronomic performance of five varieties of soybean (Glycine max) in Côte d'Ivoire. Afr. J. Agric. Res. 10(37): 3671-3677.

Naveen Kumar, R., Subhash and Reddy, R. 2018. Screening of Bradyrhizobial Isolates for Plant Growth Promoting Properties in vitro Conditions. Int. J. Curr. Microbiol. App. Sci. 7(10): 22322237. 
Nyabyenda P., 2005. Les plantes cultivées en régions tropicales d'altitude d'Afrique: généralités, légumineuses alimentaires, plantes racines et tubercules et céréales. Presses agronomiques de Gembloux. Belgique. $223 \mathrm{p}$.

Raza S., Jornsgard B., H. Abou-Taleb and J. L. Christiansen. 2001. Tolerance of Bradyrhizobium sp. (Lupini) strains to salinity, $\mathrm{pH}, \mathrm{CaCO} 3$ and antibiotics. Lett. Appl. Microbiol. 32, 379-83.

Sadowsky M. J., Keyser H. H and Bohlool, B. B., 1983. Biochemical Characterization of Fast- and Slow-Growing Rhizobia that Nodulate Soybeans. Int. J. of Systematic Bacteriology, 33(4), 716722.

Sharma M. P., Srivastava K and Sharma S. K., 2010. Biochemical characterization and metabolic diversity of soybean rhizobia isolated from Malwa region of Central India. Plant Soil \& Environment, 56(8), 375-383.

Sharma S., Upadhyay R.G. and Sharma C.R. 2000. Effect of Rhizobium inoculation and nitrogen on growth, dry matter accumulation and yield of black gram (Vigna mungo). Legume Resaerch, 23(1): 64-66.

Somasegaran P and Hoben H. J., 1994.
Handbook for Rhizobia Methods in Legume- Rhizobium Technology, springer Verlag, New York, USA. pp. 58-101.

Vincent J.M., 1970. A manual for the practical study of root-nodule bacteria. Blackwell Scientific, Oxford, UK.

Vitosh M. L., 1997. Soybean inoculation in Michigan. Soybean Facts Winter, Department of Crop and Soil Sciences, Michigan State University, USA. 4p.

Yusuf N., Nasti T.H and Meleth S., 2009. Resveratrol enhances cell-mediated immune response to DMBA through TLR4 and prevents cutaneous carcinogenesis. In cooperation with the University of Texas MD Anderson Cancer Center 48 (8): 713-723.

Zablotowicz, R. M. and Reddy K. N., 2004. Impact of Glyphosate on the Bradyrhizobium japonicum symbiosis with Glyphosate-resistant transgenic soybean: a minireview. J. Envir.Quality. 33: 825-831.

Zerhari K., Aurag J., Khbaya B., Kharchaf D and Filali-Maltouf A., 2000. Phenotypic characteristics of rhizobia isolates nodulating Acacia species in the arid and Saharan regions of Morocco. Lett. Appl. Microbiol. 30, 351-357.

\section{How to cite this article:}

Amani Kouadio, Konate Ibrahim, Mako François De Paul N'gbesso, Attien Yao Paul, Lassina Fondio, Abdelkarim Filali-Maltouf and Tidou Abiba Sanogo. 2019. Phenotypic and Symbiotic Diversity of Rhizobia Isolated from Root Nodules of Soybean [Glycine max (L.) Merrill] in Côte d'Ivoire. Int.J.Curr.Microbiol.App.Sci. 8(03): 766-774. doi: https://doi.org/10.20546/ijcmas.2019.803.094 